around the world under Lieutenant Charles Wilkes, who not only went to Antarctica but whose shore parties contributed to our knowledge of Mount Shasta in northern California. Hanley also devotes a chapter to the whalers, including the novelist Herman Melville who was a crew member in the bloody business "until he jumped ship at Marquesas Island in July, 1842, preferring to live among cannibals".

And finally comes the first writer and naturalist in Hanley's collection who looked at nature as a whole, with sympathy. Did Thoreau's words exert much influence? Probably not, but we are discovering them anew. $\mathrm{He}$ is a charming prophet.

In the following chapter, Agassiz and Asa Gray differed over Darwin's ideas without adding much to them, and they gave Harvard an early taste of dissension among its faculty.

Academic nastiness accompanies Cope and Marsh in their disputes over priority of publication, ownership of specimens, money, and anything else handy one feels. Living reptiles and amphibians found a specialist in J. E. Holbrook.

Elliott Coues was an improbable cavalryman, briefly a member of the mystical Theosophical Society of India, a superb ornithologist whose description and advocacy of bird identification using a shotgun is illuminating. Hanley progresses from the "I do not protect birds, I kill them" school of ornithology to preservationist attempts to stop some of the slaughter of wildlife. First, to stop commercial use of bird skins to decorate women and, later, to save enough big game so hunting could continue. Protagonists of the latter crusade included W. T. Hornaday and Theodore Roosevelt. In the western US, John Muir took up some of the same themes Thoreau had broached in the east. $\mathrm{He}$, too, was ahead of his time in suggesting that not every last resource should be used up by the generation then in propertied possession.

Popularisers of Natural History such as John Burroughs and Ernest Thompson Seton aroused interest in the life histories of mammals in general. If Seton was an egotist, he also had much field experience and was a competent mammalogist. Burroughs deliberately kept the observer (himself) in the forefront of his observations and descriptions, to the detriment of both. Louis Agassiz Fuertes seems to have been a paragon, not only as a painter of birds but as a fine field companion.

An appreciation of the place of predators in the scheme of nature began to appear only with C. Hart Merriam, working within the government. Aldo Leopold progressed to this view, wrote a textbook which made wildlife management a field of study, and suggested a philosophy of land use in consonance with Thoreau's ideas. But their ideas are still ahead of the economic and commercial mores of our time. Our time is one of continuing pollution of our environment, and Rachel Carson has the last chilling word.

Each person will have his own list of people, quotes, ideas, landmarks, interactions left out of Hanley's little book. The early geologists such as Gilbert, Dutton, Powell, Russell in the western US, and the early ecologists such as

\section{Running a bird reserve}

Minsmere: Portrait of a Bird Reserve. By Herbert Axell and Eric Hosking. Pp. 256. (Hutchinson: London, 1977.) $£ 7.50$.

BASICALly, as its title suggests, this is the story of the setting up and running of a reserve. It is also, however, rather more than that. Minsmere, on the Suffolk coast, is one of the largest and most famous reserves run by the Royal Society for the Protection of Birds (RSPB), and the author was the warden of the reserve for 17 years and was responsible for many of the innovations carried out there.

Before the last war, Minsmere was a low-lying area of farmland, vulnerable to flooding by the sea. In June 1940 , it was intentionally flooded as part of Britain's coastal defences against possible invasion by the Germans. In short, the birds approved and by the end of the war a number of rare species were established there. In 1947, the RSPB acquired a lease of the new marshes, together with adjacent areas of heath and woodland

The book describes the birds of all the Minsmere habitats, giving particular prominence to those that are rare elsewhere in Britain. There are four of these; three-the Bittern, Marsh Harrier and Bearded Tit-are reed-bed birds. Once common over wide areas of Britain, these species have slowly dwindled with the general drainage, particularly of the Fens. The Marsh Harrier and Bittern are reduced to very small numbers in the UK at present, indeed at one stage Marsh Harriers bred nowhere apart from Minsmere. It is one of those wry complexities which nature all too frequently sets for conservationists, that anxious parent Bitterns occasionally satisfy the needs of their clamouring young with baby Marsh Harriers from an adjacent nest. The Bearded Tit is more numerous than the other species and at the
Forbes, Clements, Cowles, Harper, Kearney, Sears, Weaver would be mine. But even if the scope of American Natural History over the past 200 years seems occasionally to approach a Boston ornithologistdowager's view, Hanley has produced a wonderfully readable and useful account. I hope it will stimulate readers to learn more of the background of our present ecological crises and the science that works toward their solution.

Jack Major is Professor of Botany at the University of California at Davis.

moment more widespread. It was, however, once scarcer and at that time Minsmere was the essential base from which, at a later date, the other colonists spread out.

Maintaining habitat in the stage at which the birds need it, is not just a matter of sitting about; it needs active management. This is especially the case with the fast growing reed-beds. The author not only discusses his dayto-day problems, but also describes new developments which he initiated. Over a series of winters (sô the breeding birds would not be disturbed), bulldozers gradually made a series of shallow pools, now famous as "The Scrape". To these, and their gravelcovered islands, birds came in large numbers. Among these were the terns, whose nesting areas along the beach were almost ceaselessly disturbed by people; and waders, whose shallow feeding areas are now so scarce. The other bird to approve of these moves was the Avocet-the fourth species to merit a chapter to itself. With only one other nesting colony in Britain (on Havergate, another RSPB reserve), this was a welcome development.

Perhaps one of the points that emerges from this book is how successful a man-made marsh can be. One cannot, at will, reproduce a mature oakwood, but one can reproduce quite quickly many of the necessary features of a marsh. As drainage relentlessly goes on, perhaps more organisations could be persuaded to find low-lying land which could be used to make amends, albeit in a small way, for some of the losses.

The book is beautifully and profuscly illustrated, mostly by Eric Hosking's own photographs. My only criticism is that some of the colour photographs are reproduced at six to 1 page, and the small size does not permit one to fully appreciate their quality.

C. M. Perrins

C. M. Perrins is Director of the Edward Grev Institute of Field Ornithology, University of Oxford, UK. 